\title{
ANALISIS PERBEDAAN PENGGUNAAN METODE PENGAKUAN PENDAPATAN MARGIN MURABAHAH TERHADAP KUALITAS LABA \\ (Studi Kasus pada Bank Syariah di Indonesia Tahun 2011-2013)11
}

\author{
Dwi Wulan Ramadani \\ Program Studi S1 Ekonomi Islam-Fakultas Ekonomi dan Bisnis- Universitas Airlangga \\ Email : dwi.wulanr@hotmail.com \\ Noven Suprayogi \\ Depatemen ekonomi syariah - fakultas ekonomi dan bisnis - universitas airlangga \\ Email : noven2005@gmail.com
}

\begin{abstract}
:
This study aims to determine the presence or absence of differences in the earnings quality on murabaha margin revenue recognition. The sample used in this study selected by purposive sampling method. It produces 6 Islamic Banks (BUS) in Indonesia with the data obtained from their annual reports that have already been published. The research used a quantitative approach using equations of regression to detect the presence or absence of earnings management, which then in different test using independent t-test. The variable in this study is earnings quality that is categorised based on the use of murabaha margin revenue recognition method. Results shows that differences in using murabaha margin revenue recognition method has an impact on quality of earnings. However, the statistical test indicated that there was no significant difference to the quality of earnings.
\end{abstract}

\section{Keywords: Murabaha, Margin Revenue Recognition, Quality of Earnings}

\section{PENDAHULUAN} Latar Belakang

Dalam pelaporan keuangan, setiap entitas bisnis diberikan kebebasan tertentu dengan batasanbatasan tertentu untuk menentukan pilihan kebijakan yang disesuaikan dengan tujuan perusahaan agar mencapai hasil yang maksimal. Namun demikian, kebijakan yang saat ini berlaku masih memiliki beberapa kelemahan dan memberikan celah kepada para pelapor keuangan untuk melakukan permainan didalamnya.

"To counter the drawbacks of reported accounting earning, and to help align a firm's accounting earnings with its economic earnings, financial statement users should assess the "quality" of a company earnings. Earning quality is defined as the degree of correlation between a company's accounting income and its economic income. several techniques may be used to assess earnings quality" (Schoeder dkk., 2005 :148).

Mengacu pada nash-nash Al-Qur'an dan ciri-ciri pelaporan akuntansi, maka dapat kita rasionalisasikan sebagai prinsip- prinsip akuntansi (Hidayat, 2010 : 284) Kualitas laba dapat diindikasikan sebagai kemampuan informasi laba memberikan respon kepada pasar. Dengan kata lain, laba yang dilaporkan memiliki kekuatan respon (power of response) (Boediono, 2005:5)

Seperti yang disebutkan Browm dalam Schroeder, dkk (2005:126) "The primary objectives of financial accounting is to provide information useful to investors in making predictions about enterprise performance. The emergence of income reporting as the primary source for investor decision making has been well documented, and income reporting aids economic society in a variety ways".

1 Jurnal ini merupakan bagian dari skripsi Dwi Wulan R, NIM : 041114029 , yang diuji pada 3 November 2015 
Ramadani, et al/Jurnal Ekonomi Syariah Teori dan Terapan Vol. 3 No. 9 September 2016: 699-712; ANALISIS PERBEDAAN PENGGUNAAN METODE PENGAKUAN PENDAPATAN MARGIN MURABAHAH TERHADAP KUALITAS LABA (Studi KasUs pada Bank Syariah di Indonesia Tahun 201 1-2013)

Intinya, laba yang tinggi belum tentu merefleksikan perusahaan berada dalam posisi yang baik pada saat terjadinya pelaporan kevangan. Rahman dalam Hamdi dan Zarai (2013) menyatakan "... if such accountability and full disclosure concepts are required in Islam, then the emphasis of Islamic corporate reporting practices would be more extensive and more reliable than conventional reporting practices".Sehingga dalam pelaporannya, segala bentuk perlakuan terhadap laporan keuangan harus dilaporakan, terutama dalam islam sendiri menjunjung tinggi nilainilai kejujuran dalam bertransaksi, seperti yang diungkapkan HR. Al-Quzwani yang di jelaskan Hidayat (2010), bahwa "Tidak dibenarkan seorang muslim menjual satu jualan yang mempunyai aib, kecuali ia menjelaskan aibnya".

Pernyataan Sulistiawan (2011) diatas didukung oleh pernyataan Scott (2011:347) mengenai pendapatan:

"Unfortunately, net income is not fully informative about effort. One reason is poor corporate governance, such as weak internal controls, which allow random error or bias into net income. Recognition lag is another reason, since, as mentioned above, several components of manager effort may not fully pay off during the current period".

Earning management is another aspect of the quality of earning issue. Schroeder dkk., (2011:149). Dalam penyataan scott menjelaskan bahwa salah satu hal yang berpengaruh terhadap kegiatan earning management dalam pelaporan keuangan adalah adanya pilihan kebijakan akuntansi dalam hal tertentu yang memberikan kesempatan kepada akuntan untuk menentukan pilihan kebijakan yang paling menguntungkan bagi perusahaan. Scott juga merangkum pola umum yang banyak dilakukan dalam praktik earning management, yakni taking a bath, income minimization, income maximization, dan income smoothing. Pola-pola tersebut menunjukkan kecenderungan pada bagian tertentu dalam perusahaan yang di intervensi oleh tindakan manajemen laba, atau lebih singkatnya bisa disebut dengan strategi dalam manajemen laba.

Dengan demikian dalam manajemen laba sehubungan pembiayaan, Utamanya pada pembiayaan Murabahah (dalam penelitian ini) yang mengacu pada Pernyataan Standar Akuntansi Keuangan (PSAK) no. 102 Revisi tahun 2013, Bank Syariah diberikan pilihan pada metode pengakuan pendapatan margin murabahahnya.

Dikaitkan dengan teori Scott sebelumnya tentang manajemen laba, maka hal tersebut memberikan peluang kepada Bank Syariah untuk melakukan manajemen laba sehubungan dengan pengggunaan metode pengakuan pendapatan margin murabahah, dikarenakan metode anuitas yang di terapkan pada BUS hampir mirip dengan penerapan di bank konvensional, dimana pada praktikanya mengakui pendapatan margin lebih agresif di awal dibandingkan dengan metode proporsional yang flat sepanjang masa akad, sehingga peluang intervensi manajemen laba pada metode anvitas dalam mengakui pendapatan margin lebih besar.

Khan (1994) menyampaikan "in the Islamic framework, the determination of true figure of profit is much more important than it is in the capitalist framework. The reason is that in a 
Ramadani, et al/Jurnal Ekonomi Syariah Teori dan Terapan Vol. 3 No. 9 September 2016: 699-712; ANALISIS PERBEDAAN PENGGUNAAN METODE PENGAKUAN PENDAPATAN MARGIN MURABAHAH TERHADAP KUALITAS LABA (Studi Kasus pada Bank Syariah di Indonesia Tahun 2011-2013) business venture in an Islamic
economy, all parties, financiers, investors, entrepreneurs, and government, are interested in a true figure profit. In a capitalistic framework, those who provide capital as credit or not ave much concern for a true profit. They are interested in their principal and interest theoreon. The banks fall in this major category. The depositors of banks also are not keen know the true figure of the bank's profit or loss. They are interested in a fixed interest on their savings. In the Islamic framework, since capital joins an enterprise on te basis of profit and loss sharing, an untrue, subjective, or manipulated figure of profit will lead to serious injustice in the society."

Demikian dengan kebijakan dalam

metode pengakuan pendapatan murabahah yang dikeluarkan oleh DSAS IAl yakni PSAK No. 102 Revisi tahun 2013 pada lembaga keuangan, memiliki 2 pilihan kebijakan. Yang pertama, metode pengakuan pendapatan margin secara proporsional, dan yang kedua metode pengakuan pendapatan margin secara anuitas. Implikasi atas 2 kebijakan tersebut membuat pelaku di industri keuangan terutama BUS untuk menggunakan kebijakan yang paling menguntungkan.

Pada kebijakan mengenai pengakuan pendapatan margin murabahah sebelumnya yang diatur oleh PSAK No. 102 Tahun 2007, hanya mengatur tentang pengakuan pendapatan secara proporsional. Seperti dilansir Dedi (2013) pada artikel dalam majalah Akuntan Indonesia yang mengungkapkan bahwa sejak saat di berlakukan PSAK no. 102

Tahun 2007 banyak menimbulkan perdebatan pada kalangan industri perbankan syariah mengenai boleh- tidaknya menggunakan metode anuitas. Ditambahkan pula pendapat mengenai banyak pemain besar bank syariah yang bersikeras untuk menerapkan metode anuitas karena dinilai cukup agresif, terutama dalam hal pengakuan margin atau laba di tahun awal. Dampak atas pengakuan pendapatan margin diawal tersebut membuat kinerja lembaga keuangan tersebut terlihat sangat baik.

Adanya perdebatan mengenai keabsahan dalam pengakuan pendapatan murabahah dipicu oleh terbitnya Fatwa MUI No. 84/DSNMUI/XII/2012 tentang metode pengakuan pendapatan pembiayaan murabahah. Dalam sebuah artikel pada majalah Akuntan Indonesia $\mathrm{KH}$. Ma'ruf Amin sebagai ketua MUI berpendapat bahwa dengan keluarnya fatwa ini berarti industri syariah bisa memilih menggunakan anuitas atau proporsional dalam pengakuan pendapatan margin murabahah. Fatwa ini muncul karena selama ini banyak perbankan syariah sudah menerapkan metode anvitas, artinya metode tersebut sudah umum dilaksanakan. Beliau berpendapat bahwa apabila anuitas diangggap tidak sah, maka laporan keuangan pada lembaga keuangan syariah bisa disclaimer.

Dengan adanya variasi pilihan kebijakan akuntansi dalam hal ini adalah pengakuan pendapatan margin murabahah, maka perusahaan akan memilih kebijakan yang paling menguntungkan bagi perusahaan. Bila 
Ramadani, et al/Jurnal Ekonomi Syariah Teori dan Terapan Vol. 3 No. 9 September 2016: 699-712; ANALISIS PERBEDAAN PENGGUNAAN METODE PENGAKUAN PENDAPATAN MARGIN MURABAHAH TERHADAP KUALITAS LABA (Studi Kasus pada Bank Syariah di Indonesia Tahun 201 1-2013)

dikaitkan dengan topik penelitian maka peneliti ingin mengungkapkan informasi mengenai ada atau tidaknya perbedaan secara signifikan dari sisi ekonomis yang diukur menggunakan variabel manajemen laba, apabila bank syariah menerapkan metode pengakuan pendapatan margin yang berbeda. Perbedaan penggunaan kebijakan dalam akuntansi yang diambil perusahaan selalu mempertimbangkan nilai ekonomisnya, sehingga sebelum mengambil keputusan, dalam hal adalah kebijakan akuntansi, perusahaan perlu mempertimbangkan kekurangan dan kelebihan masing-masing kebijakan.

Bagaimanapun kebijakan yang diambil oleh entitas bisnis islam akan selalu dikaitkan dengan aturan dalam islam itu sendiri. Namun patut dipercayai bahwa setiap tindakan dalam pengambilan keputusan juga mempertimbangkan hal yang baik pula

Berdasarkan uraian pada latar belakang diatas, maka rumusan masalah yang bisa diangkat dalam penelitian ini adalah "Apakah ada perbedaan kualitas laba di bank syariah antara bank syariah yang menggunakan metode proporsional dan atau bank syariah yang menggunakan metode anuitas dalam pengakuan pendapatan margin murabahah?"

\section{Landasan Teori}

\section{Murabahah}

Konsep jual-beli dalam Islam memiliki beberapa jenis akad jual beli, salah satunya adalah murabahah.
"Murabahah merupakan salah satu dalam prinsip jual beli, selain salam dan istishna'" (Wiroso, 2010 : 73). Dalam PSAK no. 102 revisi Tahun

2013 menerangkan bahwa "Murabahah adalah akad jual beli barang dengan harga jual sebesar biaya perolehan ditambah keuantungan yang disepakati dan penjual harus mengungkapkan biaya perolehan barang tersebut kepada pembeli".

"Murabahah was originally a sale transaction in which a trader would purchase a product required by an enduser and the will sell the product to the end-user at a price that is calculated using an agreed profit margin over the cost incurred by the trader". (labal \& Mirakhor, 2007 : 87).

Seperti halnya jual-beli secara tidak tunai, dalam penelitian ini ruang lingkupnya adalah jual-beli murabahah, dimana Al-Qur'an telah mengatur bahwa bila terjadi transaksi tidak tunai, maka harus ada pancatatannya, seperti di jelaskan ayat Al-Qur' an berikut ini; 
Ramadani, et al/Jurnal Ekonomi Syariah Teori dan Terapan Vol. 3 No. 9 September 2016: 699-712; ANALISIS PERBEDAAN PENGGUNAAN METODE PENGAKUAN PENDAPATAN MARGIN MURABAHAH TERHADAP KUALITAS LABA (Studi Kasus pada Bank Syariah di Indonesia Tahun 2011-2013)

ينأيها الذيـ. عامنوا إذا تداينتم بدين إلى أجل

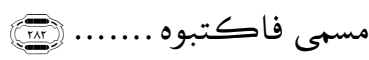

"Wahai orang-orang yang beriman, apabila kalian berutang dengan tempo tertentu maka catatlah utang tersebut..." (QS. Al-Baqarah/2 : 282, Kementerian agama Republik Indonesia, $2011: 49$ )

Sesuai dengan penyataan Hidayat (2010) yang menjelaskan mengenai etika bisnis yang di jelaskan dalam beberapa poin, dan salah satunya adalah kesadaran tentang signifikansi sosial kegiatan bisnis. Ditambahkan lagi oleh Hidayat (2010) bahwa bisnis bukan mencari keuntungan material semata, tetapi didasari kesadaran member kemudahan bagi orang lain dengan menjual barang.

"Murabahah pada awalnya merupakan konsep jual-beli yang sama sekali tidak ada hubunganya dengan pembiayaan" (Ascarya : 2008 : 82). "A typical murabahah transaction as practiced today take place between three players - the financier of the Islamic Bank, the vendor or original seller of the product, and the user of the product requiring the bank to purchase and finance on their behalf" (labal \& Mirakhor, 2007 : 87).

Sehingga, produk pembiayaan murabahah yang sekarang mendominasi pada lembaga keuangan syariah merupakan akad murabahah yang telah di modifikasi sesuai dengan skema pembiayaan untuk memenuhi kebutuhan masyarakat dalam kebutuhan pembiayaan berbasis syariah. Hasil modifikasi bukan akad jual-beli murabahah lagi, melainkan akad pembiayaan yang berbasis jual-beli murabahah

\section{Pengakuan pendapatan \\ margin murabahah}

Pengakuan pendapatan margin murabahah di Indonesia secara teknis diatur dalam Pernyataan Standar Akuntansi Keuangan (PSAK) oleh Dewan Standar Akuntansi Syariah Ikatan Akuntan Indonesia (DSAS IAI) yang di sesuaikan dengan Pedoman Akuntansi Perbankan Syariah Indonesia (PAPSI) dan Fatwa Dewan Syariah Nasional Majelis Ulama Indonesia (DSN-MUI).

Dalam aturan tersebut salah satunya adalah memberikan pilihan kepada industri keuangan syariah untuk menggunakan metode pengakuan pendapatan margin murabahah sesuai dengan kebijakan akuntansi masingmasing bank syariah. Masing-masing metode pengakuan pendapatan margin memiliki keunggulan dan kelemahan, sehingga setiap bank syariah pastinya akan menggunakan metode yang sekiranya paling menguntungkan.

Menurut M. Jusuf Wibisana (Ketua DSAS IAl) dalam sebuah artikel (Akuntan Indonesia : 2013) menyatakan bahwa industri perbankan syariah menginginkan regulasi yang lebih agresif untuk menopang pertumbuhan yang lebih besar. 
Ramadani, et al/Jurnal Ekonomi Syariah Teori dan Terapan Vol. 3 No. 9 September 2016: 699-712; ANALISIS PERBEDAAN PENGGUNAAN METODE PENGAKUAN PENDAPATAN MARGIN MURABAHAH TERHADAP KUALITAS LABA (Studi Kasus pada Bank Syariah di Indonesia Tahun 2011-2013)

Selama ini kecenderungan bank syariah untuk menerapkan metode anuitas dikarenakan metode anuitas lebih agresif dalam hal pengakuan pendapatan margin, dimana margin yang diakui di awal lebih besar untuk metode anuitas bila dibandingkan dengan metode proporsional yang rata dalam pengakuan pendapatan margin sepanjang akad, sehingga ketika menerapkan metode anuitas dalam pengakuan pendapatan margin, pertumbuhan dan tingkat pengembalian pada bank syariah terlihat lebih besar jika dibandingkan dengan metode proporsional.

Pengakuan pendapatan margin murabahah secara proporsional dan metode anuitas sebagaimana diatur dalam Fatwa No. 84/DSN-MUI/XII/2012 memunculkan pendapat bahwa kedua metode tersebut seharusnya diatur dalam PSAK 102. Secara lebih spesifik, revisi seharusnya dilakukan atas paragraf pengakuan pendapatan. (Dasar kesimpulan dari Exposure Draft PSAK. No. 102). Ditambahkan pula bahwa PSAK 102 sebelumnya menggunakan konsep jualbeli yang tidak memisahkan menjadi transaksi jual beli dan transaksi pembiayaan. Padahal konsep jual beli dan pembiayaan diatur juga dalam PSAK yang berbeda dalam SAK Umum, yaitu PSAK 23: Pendapatan untuk transaksi jual beli dan PSAK 55, PSAK 50, dan PSAK 60 untuk pembiayaan.

\section{Kualitas Laba}

berbagai pihak atau pemakai laporan keuangan mengharapkan laporan keuangan mempunyai kualitas laba yang tinggi karena digunakan sebagai salah satu dasar untuk pengambilan keputusan kontrak, investasi maupun lainya." (Surifah :

2010). "Analyst are likely to view earning to be high quality when the earnings numberaccurately reflect the company's current operating performance, are good indicators of future operating performance and are good summary measure for assessing firm value" (Kamarudin \& Ismail :

2

014).

Kualitas laba merupakan indikator dari kualitas informasi keuangan. Kualitas informasi keuangan yang tinggi berasal dari tingginya kualitas pelaporan keuangan. (Surifah :2010) sejalan dengan pernyataan Kamarudin \& Ismail(2014) bahwa “...earning quality is based on the ability of reported earnings to quickly and precisely reveal a firm's fundamental earning"

Lara et al (2008) menyatakan bahwa mengukur kualitas laba dengan memfokuskan pada manajemen laba dan pengaruhnya pada kendala akuntansi yang diukur dengan kondisi konservatisme, maka pengukuran kualitas laba disini akan lebih tepat bila menggunakan pendekatan perhitungan kualitas laba.

\section{Manajemen laba}

Dalam sebuah perusahaan 
Ramadani, et al/Jurnal Ekonomi Syariah Teori dan Terapan Vol. 3 No. 9 September 2016: 699-712; ANALISIS PERBEDAAN PENGGUNAAN METODE PENGAKUAN PENDAPATAN MARGIN MURABAHAH TERHADAP KUALITAS LABA (Studi Kasus pada Bank Syariah di Indonesia Tahun 201 1-2013)

laba merupakan salah satu fokus utama dalam menjalankan bisnisnya, dan saat ini yang menjadi perhatian akademisi adalah tentang adanya parktik manajemen laba dalam suatu entitas bisnis, seperti yang dinyatakan oleh Fillip \& Raffournier (2014) bahwa "...earning management has received considerable attention from academics, to the point that there is now an extensive body of research on determinants and consequences of the manipulation of earning". Sehingga disini ada hal yang menarik mengenai earning management yang bisa digunakan sebagai bahan acuan untuk penelitian selajutanya. Menurut Scott (2011) "Earning management is the choice by a manager of accounting policies, or real actions, affecting earnings so as to achieve some specific reported earnings objective". Bisa diartikan bahwa earning management berkaitan dengan pilihan kebijakan akuntansi yang diambil suatu perusahaan untuk memperlakukan laba agar performance laba seperti yang diharapkan perusahaan.

Selain itu seperti yang diungkapkan Sun dan Rath (2009) bahwa " A common assumption in incentive based studies of earning management is that managers use this flexibility to distort financial information in order to maximize their own utilities". Dalam hal ini banyak kemungkinan para pemegang kepentingan pada perusahaan lebih berupaya untuk mementingkan kepentingan dirinya untuk memperkaya diri sendiri. Seperti penyataan Subramanyan (1996) dalam Hamdi dan Zarai (2013) bahwa "Earning Management is opportunistic if executives use their discretion to maximize their personal utility instead of communicating inside information about firm profitability".

\section{Metode Penelitian}

\section{Pendekatan penelitian}

Penelitian kuantitatif ini merupakan penelitian yang menggunakan uji hipotesis berdasarkan data yang terukur, yakni data dari annual report pada masing-masing perbankan syariah mulai tahun 2007-2014 yang telah dilakukan serangkaian pengujian untuk menghasilkan nilai Discretionary Accruals sebagai ukuran manajemen laba.

\section{Identifikasi Variabel}

Variabel yang digunakan dalam penelitian ini adalah Manajemen Laba. Manajemen laba merupakan salah satu cara dari berbagai cara untuk menilai kualitas laba seperti penyataan Schroeder dkk., (2011:149) "Earning management is another aspect of the quality of earning issue."

\section{Definisi operasional variabel}

Manajemen Laba di deteksi dengan menggunakan parameter discresionary accruals (DA) yang merupakan nilai atas Total accruals (TAC) yang diselisihkan dengan nilai Non-Discretionary Accruals. Berikut adalah tahapan deteksi manajemen laba untuk memperoleh nilai DA. Dimana nilai DA merupakan nilai Accruals yang dipengaruhi oleh adanya 
Ramadani, et al/Jurnal Ekonomi Syariah Teori dan Terapan Vol. 3 No. 9 September 2016: 699-712; ANALISIS PERBEDAAN PENGGUNAAN METODE PENGAKUAN PENDAPATAN MARGIN MURABAHAH TERHADAP KUALITAS LABA (Studi Kasus pada Bank Syariah di Indonesia Tahun 2011-2013)

kebijakan akuntansi, yang dalam penelitian ini kebijakan akuntansi yang dimaksud adalah kebijakan dalam pengakuan pendapatan margin murabahah.

\section{Populasi \& sampel}

Populasi adalah wilayah generalisasi yang terdiri atas subyek yang mempunyai kualitas dan karakteristik tertentu yang ditetapkan oleh peneliti untuk dipelajari dan kemudian ditarik kesimpulan, dapat berupa manusia, organisasi, dan bendabenda alam lainya. (Anshori dan Iswati,

2009:93). Berdasarkan definisi tersebut, populasi yang digunakan dalam penlitian ini adalah seluruh bank syariah yang sudah dinyatakan menjadi Bank Umum Syariah (BUS) di Indonesia yang jumlah populasinya mencapai angka 12.

Sampel merupakan bagian dari populasi. (Anshori dan Iswati, 2009:93). Penentuan sampel dalam penelitian ini menggunakan metode purposive sampling yaitu menentukan sampel dengan pertimbangan tertentu (Anshori dan Iswati, 2009:105). Pertimbangan yang dilakukan dalam penelitian ini adalah dengan menetapkan batasan-batasan yang sesuai. Batasan-batasan yang ditetapkan sebagai kriteria sampel pada penelitian ini adalah sebagai berikut;

1. Bank Syariah yang dalam pengakuan pendapatan margin murabahah menggunakan metode proporsional dan atau metode anuitas
2. Bank Syariah yang konsisten menggunakan metode pengakuan pendapatan margin murabahah yang sama dalam beberapa tahun terakhir.

\section{Teknik analisis}

Teknik analisis dalam penelitian ini menggunakan analisis statistik, statistik merupakan kumpulan dari beberapa metode yang digunakan untuk menghasilkan kesimpulan suatu data. (Anshori dan Iswati, 2009:1 16). Statistik yang digunakan dalam penelitian ini adalah statistik parametrik dengan menggunakan uji hipotesis independen sampel. Analisis ini digunakan untuk membandingkan kualitas laba dengan variabel manajemen laba antara bank syariah yang menggunakan metode pengakuan pendapatan margin murabahah proporsional dan atau metode pengakuan pendapatan margin murabahah anuitas.

Tahapan analisis data yang dilakukan dalam menguji hipotesis dalam penelitian ini adalah sebagai berikut:

1. Menentukan sampel sesuai prosedur penentuan sampel penelitian

2. Menentukan nilai discretionary accruals untuk mengetahui ada atau tidaknya manajemen laba dalam pengelolaan dana di bank syariah berikut;

$$
D A_{j t}=\left(T A C_{j t} / A_{j t}\right)-N D A_{j t}
$$

3. Melakukan uji normalitas data pada hasil perhitungan manajemen laba untuk menguji data tersebut terdistribusi normal atau tidak terdistribusi normal 
Ramadani, et al/Jurnal Ekonomi Syariah Teori dan Terapan Vol. 3 No. 9 September 2016: 699-712; ANALISIS PERBEDAAN PENGGUNAAN METODE PENGAKUAN PENDAPATAN MARGIN MURABAHAH TERHADAP KUALITAS LABA (Studi Kasus pada Bank Syariah di Indonesia Tahun 2011-2013)

sebelum melakukan uji hipotesis pada penelitian ini. Uji normalitas dalam penelitian ini adalah one sampel Kolmogorov-smirnov test dengan tingkat signifikansi $5 \%$.

4. Melakukan uji hipotesis pada variabel manajemen laba untuk mengetahui ada atau tidak ada perbedaan yang signifikan terhadap kualitas laba pada bank syariah pengakuan pendapatan murabahah Uji hipotesis dilakukan dengan prosedur sebaggai berikut:

Hoeq $: \mu_{1}=\mu_{2}=$ Terdapat perbedaan yang tidak signifikan terhadap kualitas laba antara metode pengakuan pendapatan murabahah proporsional dan anvitas dengan metode pengakuan pendapatan anuitas

$H_{1 e q}: \mu 1 \neq \mu_{2}=$ Terdapat perbedaan yang signifikan terhadap kualitas laba antara metode pengakuan pendapatan murabahah proporsional dan anvitas dengan metode pengakuan pendapatan anuitas

a. Menentukan tingkat signifikansi $(\alpha)=$ $5 \%$

HO diterima apabila pvalue $\geq \alpha=5 \%$

$\mathrm{H} 1$ diterima apabila pvalue $\leq \alpha=5 \%$

b. Memberikan interpretasi hasil uji hipotesis dan melakukan penarikan kesimpulan atas penelitian yang telah dilakukan sebagai bagian akhir dari penelitian

\section{Hasil Dan Pembahasan}

\section{Nilai Discretionary Accruals}

Sebelum mencari nilai DA maka yang perlu dilakukan adalah lebih dulu mengetahui nilai total accruals (TAC)dengan cara mengurangkan net income dengan cash flow operation, hal ini dilakukan karena pendapatan yang terdapat pada suatu entitas tak hanya berasal dari transaksi riil melalui aliran kas, namun banyak pendapatan yang diakui berdasarkan nilai akrual. Setelah itu melakukan uji Regresi untuk mencari nilai parameter yang akan digunakan untuk mencari nilai Non discretionary accruals (NDA) dengan rumusan sebagai berikut;

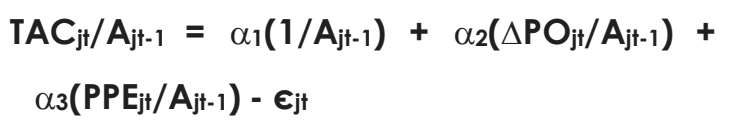

Dari persamaan tersebut menghasilkan nilai koefisien yang ditunjukkan tabel berikut;

Tabel 1.

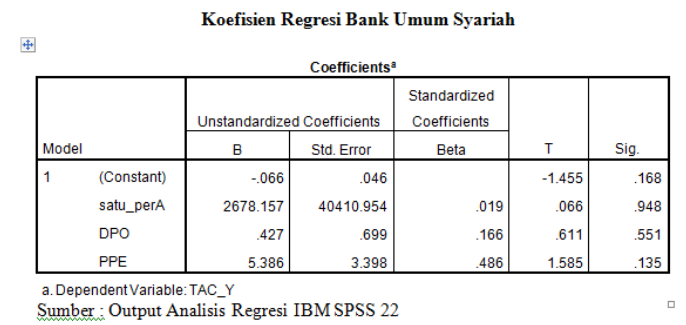

Setelah itu memasukan koefisien dalam persamaan NDA sebagai berikut;

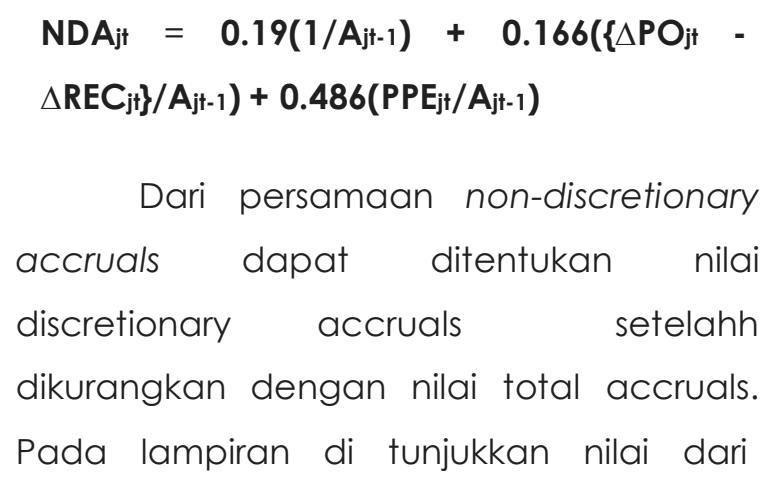

Dari persamaan non-discretionary accruals dapat ditentukan nilai discretionary accruals setelahh dikurangkan dengan nilai total accruals. Pada lampiran di tunjukkan nilai dari 
Ramadani, et al/Jurnal Ekonomi Syariah Teori dan Terapan Vol. 3 No. 9 September 2016: 699-712; ANALISIS PERBEDAAN PENGGUNAAN METODE PENGAKUAN PENDAPATAN MARGIN MURABAHAH TERHADAP KUALITAS LABA (Studi KasUs pada Bank Syariah di Indonesia Tahun 2011-2013)

discretionary accruals untuk sampel diteliti. Dapat diketahui nilai discretionary accruals bertanda "-" yang berarti bahwa praktik manajemen laba yang banyak dilakukan bersifat income minimization (penurunan laba). Lalu, nilai DA dihitung dengan menggunakan persamaan sebagai berikut;

$$
\text { DA }=\text { TAC }- \text { NDA }
$$

Tabel 2.

Hasil Perhitungan Discretionary Accruals

\begin{tabular}{|c|c|r|r|r|}
\hline \multirow{2}{*}{ Metode Akuntansi } & & \multicolumn{3}{|c|}{ Discretionary Accruals } \\
\hline \multirow{3}{*}{ proporsional \& Anuitas } & Bank & 2011 & 2012 & 2013 \\
\hline \multirow{3}{*}{ Anuitas } & BNIS & -0.2108 & -0.2284 & -0.187 \\
\cline { 2 - 5 } & MGS & -0.1761 & -0.1907 & -0.1451 \\
\cline { 2 - 5 } & BMI & -0.1563 & -0.1555 & -0.1359 \\
\hline & BSM & -0.1858 & -0.1301 & -0.2376 \\
\cline { 2 - 5 } & BCAS & -0.179 & -0.2497 & -0.1707 \\
\cline { 2 - 5 } & BRIS & -0.2064 & -0.2107 & -0.1515 \\
\hline
\end{tabular}

Sumber : Hasil penelitian, 2015 (diolah)

\section{Uji Normalitas}

Uji normalitas bertujuan untuk memastikan apakah dalam model, variabel pengganggu, atau residual memiliki distribusi normal, secara statistik disebutkan tidak ada data yang menyimpang (outliers). Oleh karena itu, dilakukan pengujian normalitas pada nilai yang dihasilkan oleh model regresi. Prosedur uji normalitas dilakukan dengan uji statistik non-parametrik KolmogorovSmirnov Test. Kriteria data dinyatakan normal atau tidak normal adalah sebagai berikut;

1. Jika signifkansi uji kolmogorov-smirnov lebih besar dari 0.05 (pvalue > 0.05), maka data terdistribusi normal.

2. Jika signifikansi uji kolmogorov-smirnov lebih kecil dari 0.05 (pvalue < 0.05), maka data tidak terdistribusi normal.
3. Selain penentuan dari nilai signifikansi, normalitas juga harus memenuhi jumlah sampel yang akan di uji, dinyatakan normal apabila sampel $n \geq$ 30.

Tabel 3.

Hasil Nilai Signifikansi Uji Kolmogorov-Smirnov

\begin{tabular}{|c|c|c|c|c|}
\hline Sampel Bank & N & $\begin{array}{c}\text { Test } \\
\text { statistic }\end{array}$ & Sig. & Keterangan \\
\hline DA_Proporsional\&anuitas & 9 & 0.184 & 0.20 & Tidak normal \\
\hline DA_Anuitas & 9 & 0.112 & 0.20 & Tidak normal \\
\hline Sumber. Output IBM SPSS 22,
\end{tabular}

Berdasarkan diatas dapat diketahui bahwa uji kolmogorov-smirnov lebih besar dari 0.05 untuk semua data yang di uji normalitas, baik bank dalam kategori metode proporsional dan atau anuitas. Namun karena masing-masing kelompok bank memiliki jumlah sampel yang tidak memenuhi 30 sampel, maka data dinyatakan tidak normal. Sehingga, dari hasil uji normalitas diambl keputusan untuk menguji hipotesis dengan menggunakan Mann-Whitney Test untuk mengetahui ada atau tidak ada perbedaan kualitas laba pada bank umum syariah yang menggunakan metode pengakuan pendapatan margin murabahah proporsional dan atau anuitas.

\section{Uji Beda Mann-Whitney U}

Uji mann whitney merupakan sebuah uji yang digunakan untuk melihat apakah terdapat sebuah perbedaan yang signifikan diantara dua rata-rata yang tidak saling berhubungan atau memiliki perbedaan yang jelas dengan data yang tidak nornal. Pada penelitian ini uji mann 
Ramadani, et al/Jurnal Ekonomi Syariah Teori dan Terapan Vol. 3 No. 9 September 2016: 699-712; ANALISIS PERBEDAAN PENGGUNAAN METODE PENGAKUAN PENDAPATAN MARGIN MURABAHAH TERHADAP KUALITAS LABA (Studi KasUs pada Bank Syariah di Indonesia Tahun 2011-2013)

whitney digunakan untuk melihat apakah terdapat perbedaan yang antara nilai discreationary accruals bank syariah dengan metode proporsional dan anuitas, dan nilai discreationary accruals bank syariah dengan metode anvitas yang telah dihitung selama periode tahun 2011-2013.

Tabel 4 .

Hasil Uji Beda Mann-Whitney Test

\begin{tabular}{|c|c|}
\hline \multicolumn{2}{|l|}{ Test Statistics $^{\mathrm{a}}$} \\
\hline & DA \\
\hline Mann-WhitneyU & 33.000 \\
\hline Wilcoxon W & 78.000 \\
\hline$z$ & -.662 \\
\hline Asymp. Sig. (2-tailed) & .508 \\
\hline Exact Sig. [2*(1-tailed Sig. $)]$ & $.546^{\mathrm{D}}$ \\
\hline \multicolumn{2}{|l|}{ a. Grouping Variable: Metode } \\
\hline b. Not corrected for ties. & \\
\hline
\end{tabular}

Sumber: Output IBM SPSS 22, hasil uji beda

Berdasarkan hasil uji beda, dapat diketahui nilai uji beda Mann-Whitney Test atas sampel bank syariah memiliki nilai signifikansi 0.508 (2-tailed). Nilai 0.508 tersebut jauh di atas nilai 0.05. Hal ini menunjukkan nilai discretionary accruals yang dihasilkan tidak berbeda pada kedua kelompok sampel bank, yang menandakan bahwa tidak adanya perbedaan. Sehingga, dugaan hipotesis 1 (HO) tentang tidak terdapat perbedaan kualitas laba yang signifikan antara bank syariah yang menggunakan metode pengakuan pandapatan margin murabahah proporsional dan atau anuitas terbukti (diterima).

\section{Perhitungan nilai discretionary accruals}

Manajemen laba melalu kebijakan akuntansi merujuk pada permainan angka laba yang dilakukan menggunakan teknik dan kebijakan akuntansi (Suliatiawan, 2011
: 70). Pada penelitian ini deteksi manajemen laba dilakukan menggunakan Modified Jones Model yang menghasilkan nilai discretionary accruals. Jones (1995) merumuskan model yang juga digunakan Zahara dan Siregar (2009) untuk menghitung manajemen laba dengan acuan nilai discreationary accruals sebagai tolak ukurnya. Berikut adalah tabel hasil rata-rata nilai discreationary accrual atas sampel bank diteliti;

\section{Rata-rata nilai discreationary accruals Bank Sampel}

Tabel 5.

Rata-rata nilai discreationary accruals Bank Sampel

\begin{tabular}{|c|c|c|c|}
\hline Discreationary Accruals & 2011 & 2012 & 2013 \\
\hline Proporsional \& Anuitas & -0.1811 & -0.1915 & -0.156 \\
\hline Anuitas & -0.1904 & -0.1968 & -0.1866 \\
\hline Rata-rata (tahun) & -0.1857 & -0.1942 & -0.1713 \\
\hline
\end{tabular}

Sumber : Data Diolah Penulis (Statistik discresionary accruals)

Widjaja dan Maghviroh

(2011)

menjelaskan bahwa semakin rendah (semakin mendekati nilai nol) nilai discretionary accruals pada sebuah perusahaan berarti semakin baik kualitas laba yang dihasilkan perusahaan tersebut. Berdasarkan hasil perhitungan rata-rata diatas menunjukkan bahwa nilai accruals pada bank syariah cukup kecil karena memang perkiraan yang bersifat accruals pada bank syariah tidak begitu banyak. Sejalan dengan penelitian Zahara dan Siregar (2009) bahwa nilai rata-rata yang cenderung negatif menunjukkan bahwa nilai accruals yang ada ada bank syariah 
Ramadani, et al/Jurnal Ekonomi Syariah Teori dan Terapan Vol. 3 No. 9 September 2016: 699-712; ANALISIS PERBEDAAN PENGGUNAAN METODE PENGAKUAN PENDAPATAN MARGIN MURABAHAH TERHADAP KUALITAS LABA (Studi KasUs pada Bank Syariah di Indonesia Tahun 201 1-2013)

cenderung bersifat income decreasing (penurunan laba).

\section{Perbandingan Nilai Discreationary Accruals pada Metode Proporsional dan atau Anuitas di Bank Umum Syariah}

Hasil uji statistik dengan uji z sampel independen mengeluarkan hasil z hitung -

1.015. Hasil $z$ hitung yang negatif menunjukkan bahwa nilai rata-rata discreationary accruals kelompok satu (metode proporsional dan anuitas) memiliki rata-rata yang lebih rendah dibandingkan dengan nilai ratarata kelompok dua (metode anuitas). Hasil pengujian dengan uji $\mathrm{z}$ sampel independen menunjukkan bahwa tidak terdapat perbedaan yang signifikan antara nilai rata-rata discreationary accruals metode proporsional dan atau anuitas pada bank umum syariah di Indonesia tahun 2011-2013.

\section{Simpulan}

Hasil Mann-Whitney Test menunnjukk bahwa tidak ada perbedaan yang signifikan pada kualitas laba yang disajikan dengan nilai discretionary accruals antara kelompok bank syariah yang menggunakan metode proporsional dan atau anuitas dalam hal pengakuan pendapatan margin murabahah. Hal tersebut mengindikasikan bahwa perbedaan pilihan kebijakan akuntansi yang dipilih oleh masing-masing bank syariah tidak memiliki perbedaan. Asumsi mengenai metode anuitas tentang potensi bahwa anvitas yang lebih agresif akan membuat kemungkinan terjadinya manajemen laba lebih besar dibandingkan dengan metode proporsional. Namun, berdasarkan hasil penelitian menunjukkan tidak ada perbedaan, sehingga asumsi tersebut terbantahkan.

$$
\text { Berdasarkan perhitungan nilai }
$$

discreationary accruals dari semua sampel mulai dari bank yang menggunakan metode proporsional dan anuitas ataupun bank yang hanya menggunakan metode anuitas saja, secara umum bank syariah memiliki kuaitas laba yang baik karena rata-rata nilai discreationary accruals yang cenderung mendekati angka nol. Bahwa manajemen laba memang terjadi pada hampir seluruh bank yang menjadi sampel dalam penelitian. Tanda minus merupakan gambaran bahwa strategi yang diterapkan memiliki kecenderungan menggunakan pola income decreasing.

Hasil penelitian menunjukkan adanya pola taking a bath sebagai strategi manajemen laba yang digunakan pada bank syariah. Volatilitas pada tahun awal terlihat smooth dalam pelaporan, ditengah mengalami penurunan atau kenaikan yang sangat ekstrim pada nilai DA. Diperkirakan bahwa perusahaan melaporkan kerugian dengan tujuan agar periode berikutnya dapat melaporkan laba sesuai dengan target perusahaan.

\section{Daftar Pustaka}

Anshori, Muslich dan Sri Iswati. 2009. Buku Ajar Metodologi Penelitian Kuantitatif. Surabaya: Pusat Penerbitan dan Percetakan Unair.

Antonio, Syafi'i. 2001. Bank Syariah : Teori dan Praktik. Jakarta: Gema Insani

Ascarya. 2008. Akad dan Produk Bank Syariah. Jakarta : PT Raja Grafindo Persada. 
Ramadani, et al/Jurnal Ekonomi Syariah Teori dan Terapan Vol. 3 No. 9 September 2016: 699-712; ANALISIS PERBEDAAN PENGGUNAAN METODE PENGAKUAN PENDAPATAN MARGIN MURABAHAH TERHADAP KUALITAS LABA (Studi Kasus pada Bank Syariah di Indonesia Tahun 201 1-2013)

Boediono, Gideon SB. 2005. Kualitas Laba : Studi Pengaruh Mekanisme Corporate Governance dan Dampak Manajemen Laba dengan Menggunakan Analisis Jalur. Solo : UPN "Veteran" Jogjakarta

Dedi. Februari, 2013. Ketika Fatwa MUI Memicu Kisruh. Akuntan Indonesia, hlm. 6

Dedi. Februari, 2013. Polemik Anuitas di Bank Syariah. Akuntan Indonesia, hlm. 6

Dewan Standar Akuntansi Syariah. 2013. Peraturan Standar Akuntansi Kevangan : Akuntansi Murabahah (PSAK No. 102). Ikatan Akuntan Indonesia

Dewan Syariah Nasional. Fatwa No. 84/DSNMUI/XII/2012 tentang Metode Pengakuan Keuntungan al-tamwil bi al-murabahah (Pembiayaan Murabahah) di Lembaga Kevangan Syariah. 2012. Jakarta : Majelis Ulama Indonesia

Esteban, Laura Parte and Garcia, Cristina Ferrer. 2014. The Influence of firm characteristic on earning quality. International Journal of HouspitalityManagement 42 (2014) 50-60

Fillip, Andrei \& Raffournier, Bernard. 2014. Financial Crisis and Earnings Management

: The European Evidence. The international journal of accounting 49 (2014) 455-478

Hamdi, Faouzi M \& Zarai, Mohamed A. 2013.

Perspectives of Earnings Management in Islamic Banking Institutions. International Journal of Business and Management

Invention. ISSN (print) : 2319-801X

Hidayat, Mohammad. 2010. An Introduction to The Sharia Economic. Editor : Luthfi Yansyah. Jakarta : Zikrul Hakim

Ikatan Akuntan Indonesia. 2013. Pedoman Akuntansi Perbankan Syariah Indonesia. Jakarta : Bank Indonesia

Iqbal, Zamir \& Mirakhor, Abbas. 2007. An Introduction to Islamic Finance. Singapore

: John Wiley \& sons (Asia) Pte Ltd

Kamarudin, Khairul A \& Ismail, Wan A. 2014. The Risk of Earning Quality Impairment. Procedia - Social and Behavioral Sciences 145 (2014) 226-236
Kamarudin, Khairul A \& Ismail, Wan A. 2014. The Risk of Earning Quality Impairment. Procedia - Social and Behavioral Sciences 145 (2014) 226-236

Khan, Muhammad Akram. 1994. Accounting Issues and concepts for Islamic Banking. London : Institute of Islamic Banking and Insurance.

Lara, juan manuel g, et al. 2008. Earnings quality in ex-post failed firms. Madrid : Spanish Ministry of Science and Innovation

Schroeder, Richard G., dkk. 2005. Financial Accounting Theory and Analysis. USA : John Wiley \& Sons, Inc

Schroeder, Richard G., dkk. 2005. Financial Accounting Theory and Analysis. USA : John Wiley \& Sons, Inc

Scott, R. William. 2009. Financial Accounting Theory, 5th edition. Toronto: Prentice- Hall Canadalnc.

Sulistiawan, Dhedy,. dkk. 2011. Creative Accounting. Jakarta ; Penerbit Salemba Empat

Sun, Lan \& Rath, Subhrendu. 2009. An Empirical Analysis of Earnings Management in Australia. International Journal of Social, Education, Economics and Management Engineering vol:3, No:7, 2009

Surifah. 2010. Kualitas Laba dan Pengukuranya. Yogyakarta: Fakultas Universitas Cokroaminoto

Utami, Danik Arianti. 2010. Analisis Komparatif Kecenderungan Manajemen Laba pada Bank Syariah, Bank Konvensional yang Mempunyai Unit Usaha Syariah, serta Bank Konvensional di Indonesia. Surabaya: Fakultas Ekonomi dan Bisnis Universitas Airlangga.

Widjaja, Fendi Permana \& Maghviroh, Rovila El. 2011. Analisis Perbedaan Kualitas Laba dan Nilai Perusahaan Sebelum dan Sesudah Adanya Komite Pada Bank-Bank Go Public di Indonesia. The Indonesian Accounting Review. Vol. 1, no. 2 , july 2011 , pages. 117-134.

Wiroso. 2010. Akuntansi Traksaksi Syariah. 
Ramadani, et al/Jurnal Ekonomi Syariah Teori dan Terapan Vol. 3 No. 9 September 2016: 699-712; ANALISIS PERBEDAAN PENGGUNAAN METODE PENGAKUAN PENDAPATAN MARGIN MURABAHAH TERHADAP KUALITAS LABA (Studi Kasus pada Bank Syariah di Indonesia Tahun 201 1-2013)

Jakarta : Ikatan Akuntan Indonesia.

Zahara \& Siregar, Sylvia Veronica. 2009.

Pengaruh Rasio Camel terhadap Praktik Manajemen Laba di Bank Syariah. Jurnal Riset Akuntanssi Indonesia vol. 12, no. 2, mei 2009, Hal.

$87-102$ 